Interdisciplinary Contexts of Special Pedagogy
NUMBER 20/2018

\title{
Well-being as a Category (Non)Present in the Teacher's Line of Thinking About Student's Success
}

\begin{abstract}
Jolanta Baran, Danuta Baraniewicz, Well-being as a Category (Non)Present in the Teacher's Line of Thinking About Student's Success. Interdisciplinary Contexts of Special Pedagogy, No. 20, Poznań 2018. Pp. 43-58. Adam Mickiewicz University Press. ISSN 2300-391X

Striving for a success in parallel to the simultaneous attainment of high level of well-being is these days a common phenomenon. For quite a long time it has been also in the focus of the scientific debates and papers also dealing with education. This paper presents the findings of the study on the teachers' perception of the student success in the context of assessment of selected success determinants and/or indicators. While analysing the theoretical relationship between student's well-being and educational success, 4 selected factors taken from the Buchner (2004) study were considered key to the undertaken research. The results showed that teachers tend to recognize factors related to the student's well-being as indicators of success, which means they perceive it as a result of achievement. Meanwhile the care for the student's well-being before undertaking an educational task as a success determinant-related situation seems to be less visible.
\end{abstract}

KEY WORDS: Well-being, success, student's educational success, teacher 


\section{Introduction}

The achievement of the above-average performance - the success in every sphere of life is now perceived as a duty, a desirable practice, and a social standard of action. We do not refer here to the stress carried by the success-related climate, but we want to emphasize that success questions such as life success, professional or educational successes has for some time been an important issue that has dominated the most important life values. This category also affects educational institutions and entities covered by the activities of teachers and students. On the other hand, whether we mean stress or satisfaction or other success-related experiences, we must refer to well-being as an important property, if we consider care for the condition of the $21^{\text {st }}$ century man, the human being of the future - and the student today. The student, for many years of institutional education, subjected to the teachers' activities, may turn out to be sensitive to a various extent to the omnipresent focus on success, also inspired by the teachers.

Meanwhile, the teacher himself is supposed to be not only the provider of the student's knowledge and skills, but also he should also show concern for his / her condition perceived holistically and called well-being.

The well-being idea is present these days in many social sciences' concepts. One of the proposed approaches to the integration of various trends and attempts to describe the structures of the sense of well-being is the three-dimensional well-being concept of C. L. M. Keyes and M. B. Waterman, "which takes advantage of the achievements of quality of life psychology, clinical and developmental theories and deliberations on health model. The concept comprises three well-being models: emotional well-being, psychological well-being and social well-being (Cieślińska, 2013, pp. 101-102). As Cieślińska writes, "three-dimensional well-being model is complex and multifaceted, it allows holistic treatment of the human being, which is one of the postulates of the so-called life-course psychology" (ibid., p. 102). 
The criteria of psychological well-being were developed by C. D. Ryff in conjunction with C. L. M. Keyes (1995, Keyes 2006). Following the authors, their well-being model comprises six dimensions (Ryff, Keyes 1995, p. 727):

1. Self-acceptance, a key aspect of well-being, which is a positive attitude towards one's self

2. Life goal, the ability to find meaning and direction in life, as well as to define and carry out life tasks

3. Personal development, or the ability to constantly use own talent and potential, as well as to develop new abilities and capabilities

4. The control over the environment, another fundamental dimension of well-being, is coping with the world around us. This skill requires the ability to create and nurture an environment that suits our personal needs

5. Autonomy, ability to act under one's own bidding, following one's own beliefs, even if they are inconsistent with the current dogma or conventional wisdom

6. Positive relationships with others, the last dimension comprises strength, pleasure and joy, which ensure close contact, deep intimacy and true love.

The analysis of the referred to dimensions of well-being allows us to recognize that their implementation simply means achieving success - generally speaking - personal, life success.

"Success belongs (...) to the interdisciplinary and universal categories. (...) The multiplicity of planes on which it occurs, the difference of its experience and the diversity of definitions make it one of the categories not easily testified empirically" (Gajdzica, 2014, p. 24). The universal Polish language dictionary defines success as "goal achievement, a successful result of some efforts, actions" (Dubisz, 2006, p. 1447). Success is "a happy end of a venture. Every success is an incentive to face another challenge" (Sillamy 1994, p. 281). It appears not only at the end of the action, but also stimulus for take further actions. However, success is not only the end or the motivation to take consecutive actions - its synonym is also, often 
unnoticed and underestimated, trying to achieve the goal. Jeffers (after Waters, 1999, p. 258) states: "You do not fail, if you refrain from action; you succeed if you try".

The contemporary "success in vogue" is reflected in the publication of the "Success Encyclopaedia" (Sztucki, 1998), as well as in numerous guides suggesting how to be successful, applying various strategies, such as coaching. In other words, more or less professional help in achieving the goal began to develop intensively. One can agree with the fact that:

"Success is the attainment a predetermined goal worth efforts and endeavours. It involves comparing yourself with your abilities. It means success, prosperity, fulfilment of task or venture undertaken. The measures of success - according to various value scales - comprise money, power, knowledge, fame and happiness"' (Sztucki, 1998, p. 316).

Similarly to well-being, the success can also be both subjective and objective. The subjective nature of success results from a personal assessment of own actions, whereas the objective nature of success is a social view, external criteria of success (Michalak, 2007). It can therefore be said that "every person must decide what success means for him and set own criteria to measure whether he has succeeded or not. (...) if we do not set such criteria (or measures) of success, others will do it for us" (Waters, 1999, p. 258). In the subjective interpretation, therefore, the success "is about the attainment of something that we intended to do, to possess, or what we wanted to become" (ibid.).

Paradoxically enough the reading of the available literature of the subject shows that even if the term of the educational success appears in the title, the content considered most often concerns failure or educational failure (for example: Przybysz-Zaremba, 2010; Piwowarski, 2007). It is also difficult to find the very definition of educational success (see the lack of it in: Pedagogical Dictionary, Kupisiewicz and Kupisiewicz, 2009; 21 ${ }^{\text {st }}$ Century Educational Encyclopaedia, edited by Pilch, 2007, New Pedagogical Dictionary by Okon, 2007). Nevertheless, in various sources there is evidence that 
there is interest in gifted student, also in terms of analysis of the causes of possible failures (e. g. Dyrda, 2007). "The success of a gifted student is (...) understood as his personal conviction about the achievement of something important for himself and others, feeling of his own success (subjective aspect), but also visible and appreciated by others results of student activities in various educational areas, expressed in the form of non-standard results of specific activities and significant achievements (objective aspect). The success of a talented student is identified with his achievements" (Uszyńska-Jarmoc, Kunat, Tarasiuk, 2014, p. 50). The presented prospect of success was based on the concept of Sękowski (2001, see also Świda-Ziemba, 2005, Boryszewska, 2008).

It is worth posing a question how to measure the educational success, especially that "striving for the highest possible performance in tests and examinations began to play an increasingly important role in the activities of educational facilities" (Chrzanowska, 2015, p. 581), and "exam efficiency" is visible in the school and student rankings (ibidem).

Meanwhile, "on the handicap, mainly of a psychometric nature, measurement tools", as Chrzanowska writes (2015, p. 580), pointed out Konarzewski or Groenwald.

Another vision of the evidence of success achieved is presented by Buchner (2004), which can be critically related to the aforementioned ranking chase, which reflects the success conceived in a specific way, i.e. the overestimation of the importance of school notes. According to the author, the child is successful at school, if (ibid., pp. 13-14):

1. Feels that he makes progress in learning;

2. Draws joy from these advances;

3. Is ready to make an effort;

4. Is able to persistently work on the task assigned to him, until he realizes it;

5. Achieves results that are appropriate to his abilities;

6. Is able to organize learning to cope with his duties;

7. Perceives learning at school as meaningful; 
8. Carries out his notebooks correctly;

9. Keeps his school supplies in order;

10. Knowledge acquired at school also uses outside school in some form of activity: book reading, reciting poems, solving tasks.

It is also worth completing the presented list of student's success measures by adding a statement, which according to Sękowski (2001) student's school achievements gives him recognition both among teachers and age peers. The need for social recognition and the recognition of achievements by others is undisputable.

"Success at school, which is expressed in the way presented, will have a longer positive impact and will bring the child greater benefits than several good grades. These often mean superficial success, which can be quickly destroyed by means of average or poor grades" (Buchner, 2004, p. 14).

\section{Method}

A teacher who helps the student to build knowledge through his inspired activities and educational interaction usually has some expectations and ideas about the progress or success of his charge. The phenomenon accompanying these situations is the definite, probably evolving, level of student's well-being, both at the threshold of action ("at the entrance") and at the end of implementation of a specific educational task ("at the exit"). The point of departure was considered to be related to the success determinants, whereas the final situation with success measures, and the role of the teacher in modifying the quality of both of them was recognised to be important.

As a part of a wider research project (currently the results are being processed for the monograph), the issues of student's wellbeing were considered as important and inseparable factor / quality attributed to its educational success. The following research question was posed: 
Is there any concern about student's well-being in teacher thinking about the student's success?

Out of the 11 factors analysed, defined by Buchner (2004) and understood as determinants or indicators of student success, 4 were chosen arbitrarily and were considered to be related in a special manner (referring to more recent definitions) with his well-being.

An own survey was developed for teachers attending postgraduate studies in the field of special pedagogy. They were asked to assess which of the factors related to the student's success they consider as determinants and which as success measures. To the avoidance of doubt, it has been explained that factors under this assessment are understood as all the success determinants (it can be said that they occur "on the way to" - "at the entrance"). The success measures, in turn, are those that testify to its existence (they are only present "at the top" - "at the exit").

The applied division of factors, taken from the Buchner study (ibidem), was a deliberate simplification in this study. The idea was to encourage reflection, not necessarily consistent with the division used, and to grasp the opinions of teachers whether their judgments reveal thinking about the student's well-being not only when he is clearly successful - but also before he appears. It was assumed that in the first case, the observed student behaviour, revealing that he is experiencing and being aware of his achievements does not need to have any connection with the teacher's appearance or lack of action to support him on the way to success. The second one, however, shows whether the teacher notices what in the student's behaviour can be a success prediction and launch the teacher's action to create conditions conducive to success.

78 complete questionnaires consisting of Part I and II were analysed. The procedure involved two stages. The teachers completed the same questionnaire, with the difference that after the respondents answered questions in Part I - requiring generalization - for all students - regardless of their abilities (a group of students called the disabled students), in Part II, teachers were instructed to speak on 
similar issues thinking about students with disabilities. It should be added that the second part, which the respondents initially did not know, was distributed after the end of the first stage.

In the group of teachers surveyed, those who worked or had previous experience in working with a disabled students and those who did not have such experience were selected. Others were numerically larger group (in the proportion of about $2 / 3$ to $1 / 3$, exactly: $65.4 \%$ to $34.6 \%$ ). Comparisons were made crosswise, i.e. in line with selected groups and including statements about all students (AS) or students with disabilities (SD).

\section{Results}

The responses selected in this study included reviews that related to the following factors:

1) the student has the feeling that he is making progress in learning

2) pupil enjoys learning progress

3) the student perceives learning at school as something meaningful

4) for school achievements, the student enjoys recognition among both teachers and peers.

Teachers' perception of the first of the factors assessed (Figure 1) indicates the belief that the student's sense of progress is the result of success, i.e. it was considered an indicator in more than half of the statements (range between $59.3 \%$ and $66.7 \%$ of responses).

Not all respondents chose between the category: conditioning indicator. Individual teachers with experience with the SD, both for all students and those with disabilities did not make an unambiguous assessment of the analysed factor. This fact shows that they take into account the interdependence of the student's behaviour with both the factors preceding the achievement and the same, i.e. as the effect of success itself. Interestingly, teachers with professional experience from the SD are less likely to believe that the student's 
sense of progress can be a prerequisite for success. Thus, they perceive this behaviour primarily as a consequence of specific achievements. Statements relating to the SD reveal an even stronger tendency, i.e. even fewer surveyed teachers are willing to consider the assessed factor as a possible conditioning of the success of these students.

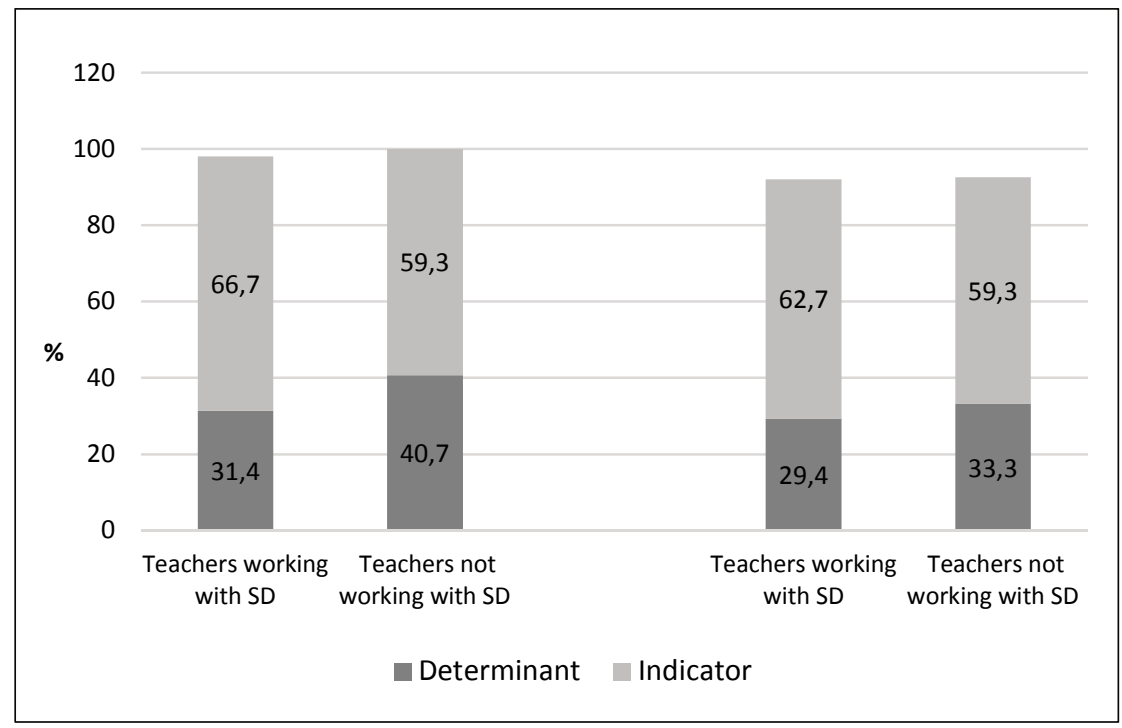

Figure 1. Factor: Student feels she/he makes progress. Teachers' opinions concerning: AS (column 1-2)/SD (column 3-4)

However, it should be noted that the student, regardless of their level of fitness, needs a prior conviction that he can and that he achieves good results. Deciding for only one category (determinant vs. measure) seems to be incorrect thinking. Recognition of this factor should not be only a succession, but also a prerequisite for success. Appropriate well-being ("feeling that progress is being made") is needed in the course, in the process, on the way to the "finish", which is every achievement, because the achievement as such 
should already be considered "being on the road", acting for success, striving at it, but also the condition before making a decision about acting or determining what you want to achieve.

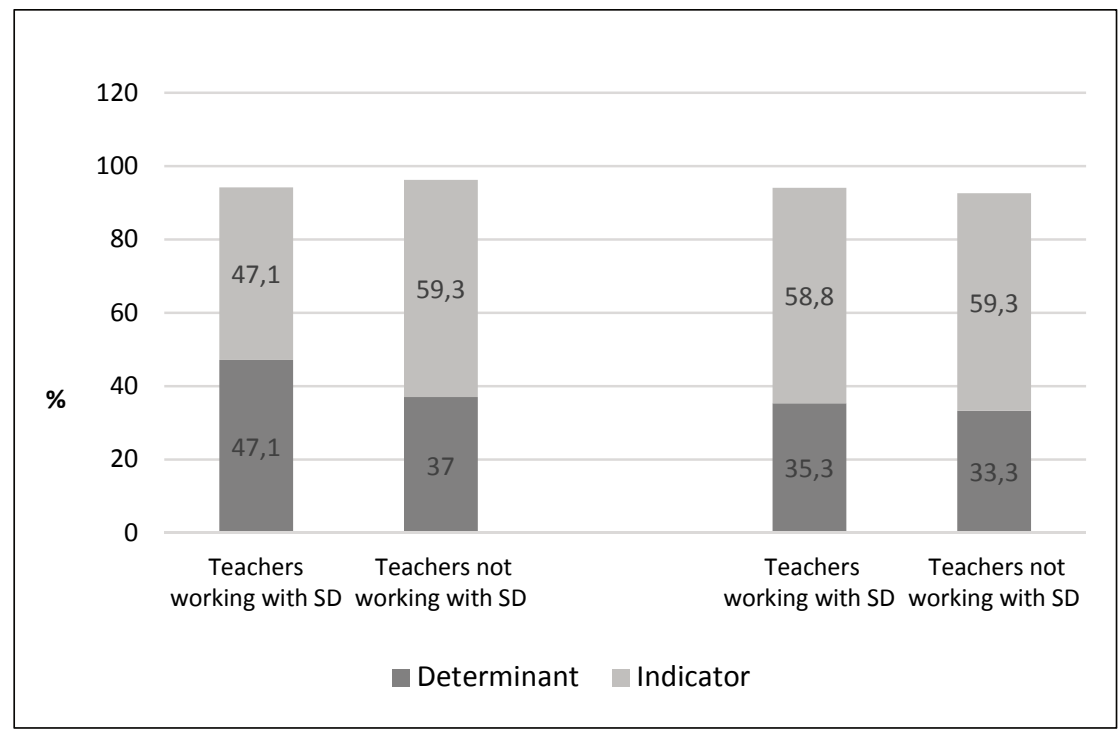

Figure 2. Factor: Student enjoys learning progress. Teachers' opinions concerning: AS (column 1-2)/SD (column 3-4)

Another factor concerns literally well-being and it clearly emphasizes the importance of its presence (Figure 2). In the content of the term "student enjoys the learning progress", his emotional dimension is clearly marked, and this seems to increase or at least pay attention to its desired level. In addition, it presumes prior positive experience in the acquisition of efficiency or knowledge.

This time, the surveyed teachers showed a greater propensity to recognize this factor as a pre-condition of success (i.e. conditioning). Slightly more frequent indications are the results between 33.3\% and $47.1 \%$ of choices, from one third to almost one half. Unlike the first factor, the order of approvals was arranged. Teachers working 
with the disabled student more often than those without such experience have admitted that progress enjoyment can be a determinant of success. Interestingly enough, the same percentage considered him as an measure, i.e. the succession of specific achievements, for all students. On the other hand, teachers without experience with the disabled students, to the same extent, i.e. 59.3\%, indicated that regardless of the student's level of proficiency, progress enjoyment during learning process is a measure, or the result of his or her achievements.

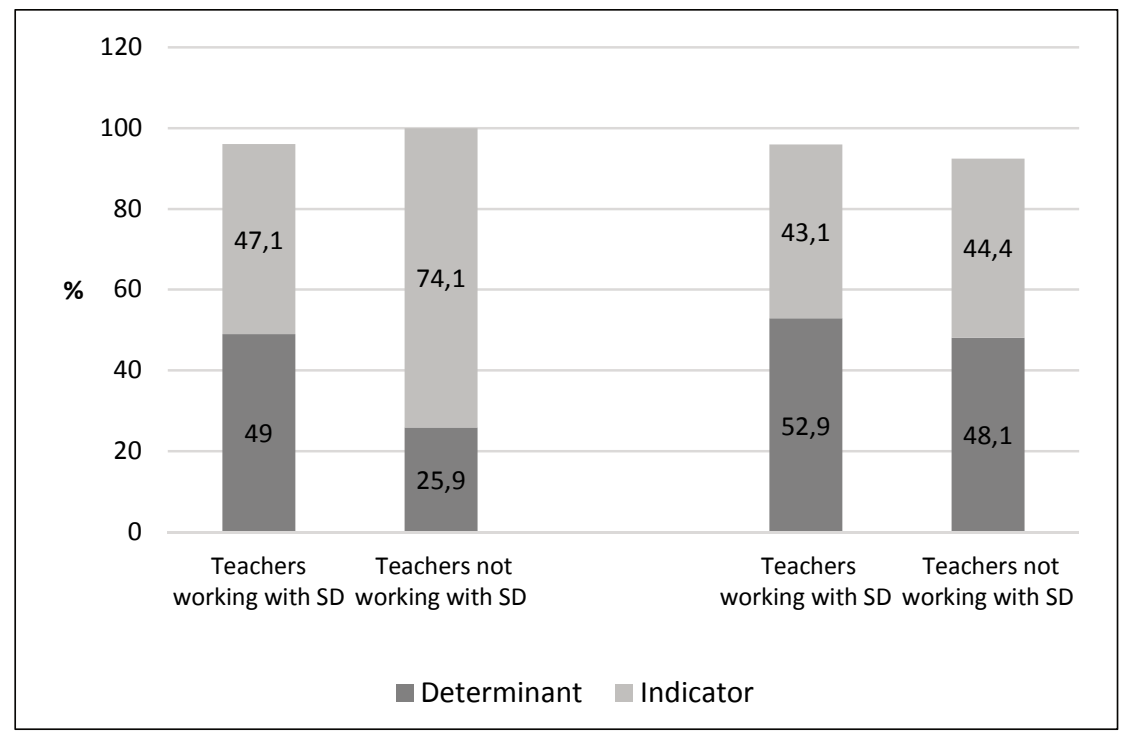

Figure 3. Factor: student perceives learning at school as something meaningful. Teachers' opinions concerning: AS (column 1-2)/SD (column 3-4)

Taking up school duties may be motivated, as we know, by various sources. Recognizing the sense of learning is an expression of its more mature form, and at the same time an attitude, and it is probably associated with a more or less conscious need to pursue personal goals in the education process. Among the well-being 
components, a sense of the meaning of life is mentioned (concept of C. D. Ryff, B. Singer, 2004). Thus, the awareness of the sense of action is important. In this context, the surveyed teachers assessed as determinant vs. success rate is another factor-wording: "the student perceives learning at school as something meaningful" (Figure 3). The obtained results show very clear differences between the group of teachers with experience and without experience of working with disabled people in teacher's thinking about the student's success.

It can be assumed that every second teacher in the first group with reference to both all students and the disabled students considers this category as a determinant of the student's success. She/he is less likely to see it as an indicator less often. Meanwhile, the teachers without experience with the disabled students strongly differentiate their assessment, depending on the student's performance. Only every fourth of them (i.e. approximately, the result obtained is $25.9 \%$ of responses) believes that in the case of all students, the perception of science as something sensible is the conditioning of their success. However, every second (result rounded up - exactly $48.1 \%$ ) for the disabled group already gives the same rating. The conclusion based on this fact comes as a surprise. Is it possible, according to this fact, to recognize that the majority of teachers believe that the sense of science is noticed by students only after obtaining positive effects?

Watching of specific phenomena of pop culture and social life (or rather "social media") suggests that being noticed or received recognition from other people (e. g. "likes", regardless of the actual reasons for the student) is nowadays a necessary condition to mark his existence and its important purpose. School as a kind of social system creates many situations that allow "to exist" or to be noticed in various ways. The factor, formulated in the discussed survey as follows: "student's school achievements are recognized both by teachers and age peers" obtained the advantage of grades as an indicator (Figure 4).

Both groups of teachers in more than half of the choices expressed such a belief. And this time, however, it can be noticed that teachers without experience of working with the disabled students 
more often expressed the opinion in relation to the disabled students. What's more, when asked about students with disabilities, they were more inclined than teachers with experience of working with these students to consider the discussed factor as a determinant of the success of these pupils. On this basis, it can be concluded that the disclosed trend speaks for the need to provide all teachers with important knowledge about this area - and not only about students with disabilities.

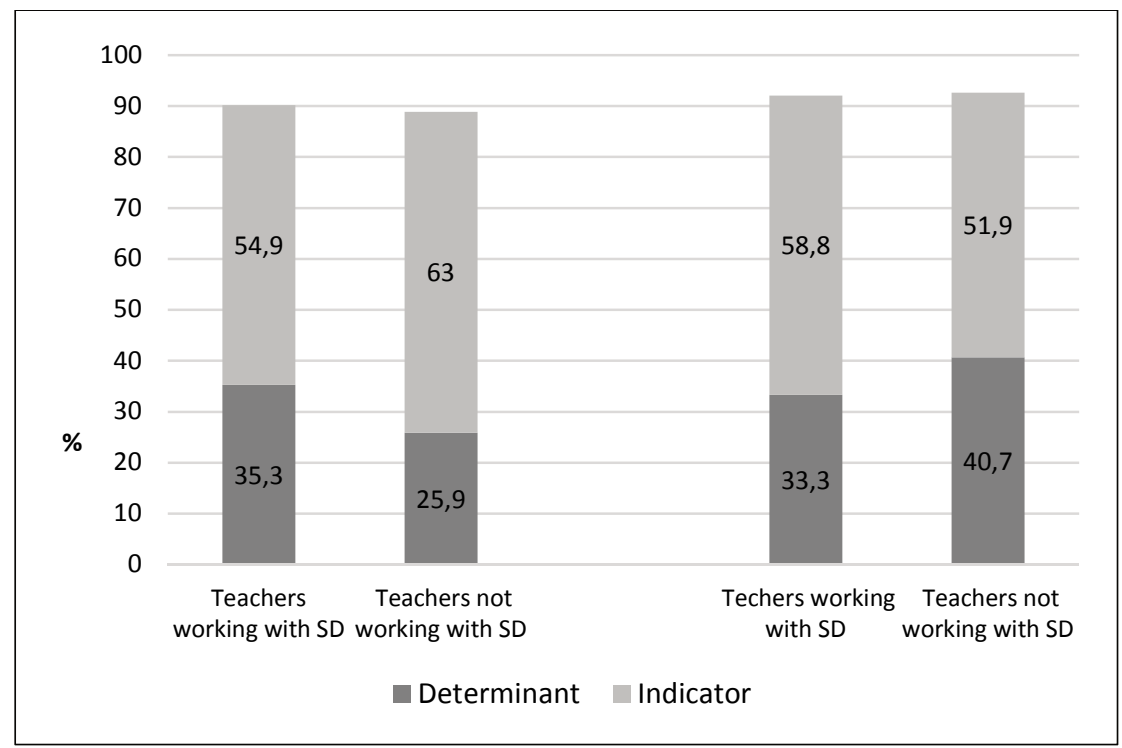

Figure 4. Factor: Student's school achievements are recognized both by teachers and peers. Teachers' opinions concerning: AS (column 1-2)/SD (column 3-4)

\section{Conclusions}

The presented teachers' opinions regarding their perception of selected factors related to the student's educational success and his well-being show a fairly clear trend. The teachers' assessment of the 
measures and determinants of the student's success is dominated by the prevalence of the factors, referring directly to well-being, recognized as success measures, rather than success determinants. In other words it implies that the majority of teachers' treats as the effect of student's educational success the student's well-being in the area selected for the study of its 4 components/factors, and less frequently as a possible conditioning of this success or both. It can be assumed that such thinking (perhaps not fully conscious) allows them to waive a part of their responsibility for possible failures that may be related to the low level of student's welfare (at the entrance), i.e. before coming across or undertaking an educational task.

Some of the responses provided by the teachers who have experience working with a student with a disability should be noted. It is amazing that in the assessment of the factor "the student perceives learning at school as something meaningful" teachers assigned to it, to a similar extent, the role of the student's initial success and the indicator, i.e. the effect of success. Thus more often than the teachers who do not work with the disabled student they perceive this factor as a possible action driver and an important dimension of student's well-being. It is difficult to disagree with their opinion. This is an important conclusion for teaching staff education.

However, it should be noted that the results obtained should not come as a surprise if you admit that the school as an institution and teachers as its main "staff" are for various reasons performanceand achievement-oriented, i.e. they focus "outputs". Focused on farfetching goals, they underestimate the importance of pre-conditions or success drivers. Meanwhile, they should exercise care for the student's well-being even before he takes an action / educational task. Proper preparation of teachers in this area, i.e. acquisition of the necessary knowledge and skills, still at the level of professional qualifications acquired by them, can not be overestimated.

Differences in thinking about the well-being and success of a student with disabilities in the context of understanding the edu- 
cational situation of any student (generally speaking) also lead to a postulate about a need of continuous update the teachers' knowledge about students with special educational needs, but also about the significance of individual differences in the process of knowledge acquisition and achieving educational successes - not according to one measure - by all students.

"The task of the educator is to adjust the difficulty of the tasks assigned to the charges for implementation, so that they proceed to their implementation without concern that they will not be able to do it. Everyone needs success; it is the determinant of the individual's value" (Sillamy, 1994, p. 281).

\section{Bibliography}

Boryszewska J. K. (2008). Źródła sukcesu szkolnego młodzieży licealnej (Sources of success of high school students), Oficyna Wydawnicza „Impuls”, Kraków.

Buchner C. (2004). Sukces w szkole jest możliwy. Jak pomóc dzieciom, by miały dobre osiagnięcia w szkole podstawowej. Poradnik dla rodziców i wychowawców (Success at school is feasible. How to help children to perform high at the primary school. Handbook for parents and educators), Wydawnictwo JEDNOŚĆ, Kielce.

Chrzanowska I. (2015). Pedagogika specjalna. Od tradycji do wspótczesności (Special pedagogy. From tradition to modern times), Oficyna Wydawnicza „Impuls”, Kraków.

Cieślińska J. (2013). Poczucie dobrostanu i optymizmu życiowego kadry kierowniczej placówek oświatowych (Feeling of well-being and life optimism of the management of educational facilities), "Studia Edukacyjne”, nr 27.

Dubisz S. (red.), (2006). Uniwersalny stownik języka polskiego (Universal Dictionary of Polish Language), PWN, Warszawa.

Dyrda B. (2007). Zjawiska niepowodzeń uczniów zdolnych (Failures of talented students), Oficyna Wydawnicza „Impuls”, Kraków.

Gajdzica Z. (2014). Kategorie sukcesów w opiniach nauczycieli klas integracyjnych jako przyczynek do poszukiwania koncepcji edukacji integracyjnej (Success categories in the opinions of inclusive education class teachers as the contribution to the search for inclusive education concept), Oficyna Wydawnicza „Impuls”, Kraków.

Groenwald M. (2011). Etyczne aspekty egzaminów szkolnych (Ethical aspects of school examinations), Wydawnictwo UG, Gdańsk.

Keyes C. L. M. (2006). Subjective Well-Being in Mental Health and Human Development Research Worldwide: An Introduction, "Social Indicators Research", No. 77, pp. 1-10. 
Konarzewski K. (1999). Komu jest potrzebna diagnoza oświatowa (Who needs educational diagnosis), [in:] B. Niemierko, B. Machowska (red.), Trafność pomiaru jako podstawa obiektywizacji egzaminów szkolnych (Effectiveness of measurement as a basis for objectivisation of school examinations), ODESiIP, Legnica.

Kupisiewicz Cz., Kupisiewicz M. (2009). Stownik pedagogiczny (Pedagogical Dictionary), PWN, Warszawa.

Michalak J. M. (2007). Uwarunkowania sukcesów zawodowych nauczycieli. Studium przypadków. (Determinants of teachers' professional successes. Case studies). Wydawnictwo Uniwersytetu Łódzkiego, Łódź.

Okoń W. (2007). Nowy stownik pedagogiczny (New Pedagogical Dictionary), Wydawnictwo Akademickie "Żak”, Warszawa.

Pilch T. (red.) (2007). Encyklopedia pedagogiczna XXI wieku (21 ${ }^{\text {st }}$ Century Encyclopaedia of Pedagogy), vol. VI, Wydawnictwo Akademickie "Żak”, Warszawa.

Piwowarski R (red.) (2007). Dziecko. Sukcesy i porażki (Child. Successes and Failures), IBE, Warszawa.

Przybysz-Zaremba M. (red.) (2010). Sukcesy i porażki w edukacji dzieci i młodzieży (Successes and Failures in the Children and Youth Education), Oficyna Wydawnicza PROSPEKT PR, Olsztyn.

Ryff C. D., Keyes C. L. M. (1995). The Structure of Psychological Well-Being Revisited, "Journal of Personality and Social Psychology", Vol. 69, No. 4, pp. 719-727.

Ryff C. D., Singer B. (2004). Paradoksy kondycji ludzkiej: dobrostan i zdrowie na drodze ku smierci (Paradoxes of human condition: well-being and health on the road to death), [w:] J. Czapiński (red.), Psychologia pozytywna. Nauka o szczęściu, zdrowiu, sile $i$ cnotach czlowieka (Positive Psychology. Science About Happiness, Health, Strength and Virtues of the Human Being), PWN, Warszawa.

Sękowski A. E. (2001). Osiągnięcia uczniów zdolnych, (Achievements of Talented Students), Towarzystwo Naukowe Katolickiego Uniwersytetu Lubelskiego, Lublin.

Sillamy N. (1994). Stownik psychologii (Dictionary of Psychology), Wydawnictwo Książnica, Warszawa.

Sztucki T. (1998). Encyklopedia sukcesu. Definicje, zasady, metody (Encyclopeadia of Success. Definitions, Principles, Methods), Agencja Wydawnicza PLACET, Warszawa.

Świda-Ziemba H. (2005). Młodzi w nowym świecie (Young People in Modern World), Wydawnictwo Literackie, Kraków.

Uszyńska-Jarmoc J., Kunat B., Tarasiuk M. J. (2014). Sukcesy uczniów zdolnych, Fakty Narracje - Interpretacje (Successes of Talended Students. Facts - Narratives - Interpretations), Centrum Kształcenia Ustawicznego w Białymstoku, Białystok.

Waters M. (1999). Stownik rozwoju osobistego. Pojęcia i teorie samodoskonalenia (Personal Development Dictionary. Self-Development Notions and Theories), Wydawnictwo MEDIUM, Kraków. 